\title{
DOES MULTINATIONAL OWNERSHIP AFFECT FIRM SURVIVAL IN ITALY?
}

\author{
Anna Maria Ferragina ${ }^{1}$, Rosanna Pittiglio $^{2}$, Filippo Reganati ${ }^{3}$ \\ ${ }^{1}$ University of Salerno, Via Giovanni Paolo II, 132 - 84084, Fisciano, Salerno, Italy \\ ${ }^{2}$ Second University of Naples, Corso Gran Priorato di Malta - 81043, Capua, Caserta, Italy \\ ${ }^{3}$ University of Roma Sapienza, Piazzale Aldo Moro, 1 - 00185, Roma, Italy \\ E-mails: 1aferragina@unisa.it; ${ }^{2}$ rosanna.pittiglio@unina2.it (correspondingauthor); \\ 3filippo.reganati@uniroma1.it
}

Received 13 September 2011; accepted 26 June 2012

\begin{abstract}
The aim of this paper is to investigate whether and how multinational status and foreign ownership affect the survival of Italian manufacturing and service firms. To this end, we analyze firm survival by distinguishing Italian firms as foreign multinationals (FMNEs) domestic multinationals (DMNEs) or domestic non-multinational firms (NMNEs). The empirical analysis is based on the Kaplan-Meier survival estimator and on the Cox proportional hazard model, in which we look for the impact of ownership dummies on firm survival, controlling for several firm and industry specific covariates. Our findings reveal that manufacturing and service firms owned by foreign multinationals are more likely to exit the market than either DMNEs or NMNEs. Moreover, DMNEs show a higher chance of survival in services. By decomposing firm activities into different technological classes, we also find that foreign ownership still exerts a negative influence on firm survival in both static and dynamic industries, while domestic multinationals in less-knowledge-intensive services appear more persistent.
\end{abstract}

Keywords: firm exit, multinational enterprises, technological intensity, Italian economy, panel data, Cox model.

Reference to this paper should be made as follows: Ferragina, A. M.; Pittiglio, R.; Reganati, F. 2014. Does multinational ownership affect firm survival in Italy?, Journal of Business Economics and Management 15(2): 335-355.

JEL Classification: C41, F23, D21, L25.

\section{Introduction}

A large body of evidence suggests an overall beneficial impact of multinational firms (MNEs) on both home and host countries. However, the issue of whether foreign MNEs are more "footloose" than domestic firms is highly debated in the political as well as in the academic field. A further but less investigated question is whether a more footloose nature can also be attributed to domestic MNEs. In this paper we analyse both issues and study the determinants of survival of three categories of firms in Italy: foreign 
multinationals (FMNEs), domestic multinationals (DMNEs) and purely domestic firms (NMNEs).

Our study contributes to the empirical literature on firm survival in several ways. First, it attempts to fill a gap in the literature as to-date the studies regarding the effects of MNEs on survival of Italian firms have not yet compared DMNEs and FMNEs exit rates. Second, by decomposing firm activities into different technological classes, it sheds some light on the impact that technological environment may have on Italian firms' survival according to their ownership status. Finally, unlike most of the empirical literature on the topic, the sample of firms used is not restricted to manufacturing sectors but also covers service sectors. To the best of our knowledge, only Van Beveren (2007) and Ferragina et al. $(2010,2012)$ have been able to extend the analysis of ownership and survival beyond the manufacturing sectors, without however considering technological heterogeneity among sectors.

Given this premise, we achieve our aims by using an unconditional analysis of survival by the Kaplan-Meyer (KM) survival estimator and then turning to a conditional analysis based on the Cox proportional hazard model (CPHM), in which we look for the impact of ownership dummies on firm survival, controlling for several covariates both at firm and industry level that may affect survival. The analysis covers the period 2004-2008.

The issues under investigation have several implications in terms of policy recommendations. To what extent does achieving a stronger degree of firm internationalisation in Italy, via both active and passive foreign investment, imply less stable and rooted firms in the economy that might further increase the high rate of mortality among Italian firms? These are relevant questions at different levels. Firms' shutdowns play a major role in the dynamics of employment and industrial restructuring. Besides, firms' birth and death contribute to industry productivity growth and shape industry competition. These facts are much more relevant for a country like Italy in which FDI performances are still far from potential and where four years after their entry, only 60 percent of Italian firms survive.

The plan of the paper is as follows. In section 1, we present the basic theoretical and empirical premises on the determinants of survival and we summarise the main empirical results of the literature. Section 2 presents the data and shows some descriptive statistics on FMNEs, DMNEs and NMNEs disaggregated by firm size. Section 3 presents the empirical methodology, and the last section - the estimation results. Finally, the last section summarises and concludes.

\section{Survival dynamics and multinational firms: a brief survey}

The factors determining the probability of firm exit have been extensively analysed in the Industrial Organization literature. In particular, there is a large body of empirical evidence which has modeled the likelihood of firm's survival as a function of several variables, designed to reflect both firm characteristics, e.g., age, size, technological level, profitability, and industry characteristics, such as, among others, market concentration, growth (see among others Dunne et al. 1988; Caves 1998). Only recently the 
literature has opened a further strand of research by trying to analyse the impact of multinational ownership on survival probability ${ }^{1}$.

Theoretically, the expected impact of multinational ownership on firm survival is ambiguous. On the one hand, the "footloose" character of MNEs is justified by the fact that, as part of an international production network, these firms can easily relocate production between countries in response to adverse shocks in the host country (FMNEs) or to changes in local costs (DMNEs). Using optimal portfolio theory, Flamm (1984) showed that US multinationals rapidly adjust their operations to changes in host country environments based on particular country risks. The exit propensity might also depend on the nature of FDI involved: if FDI is horizontal - which occurs when a firm duplicates its home country-based activities at the same value chain stage as in the host-country - then FMNEs may be less likely to close plants since they serve a target market. Conversely, vertically integrated firms might be more likely to close as they are more sensitive to changes in costs of production (Inui et al. 2009). Using data for the UK, Simpson (2008) finds that overseas investment in low-wage economies is associated with asymmetric effects on workers in low and high-skill industries in the home economy, and in particular with firms closing down plants in low-skill industries.

On the other hand, the "rooted" character of MNEs may be justified by a result that emerges from the finance literature, which analyses the impact of sunk entry costs on firm exit (Dixit, Pindyck 1994): the larger the amount of irrecoverable costs, the greater the value of waiting before making an exit decision. So, it could be argued that if the sunk costs of investing abroad are higher than those for setting up a purely domestic plant in the host country, foreign affiliates are less likely to exit. However, it should be noted that on this point the literature is quite controversial. Some authors, in fact, state that MNEs should face higher sunk costs when establishing a new firm because new firms are typically more skill- and capital-intensive than incumbent firms. Vice versa, other authors claim that MNEs, such as multi-unit enterprises, are likely to benefit from lower sunk costs in terminating plant's operations, due to the greater efficiency of their internal factor markets in re-deploying the production equipment and labour force of the closed plant (Baden-Fuller 1989).

Recent empirical work on productivity differences between firms shows that MNEs, regardless of whether they are domestic or foreign-owned, exhibit a "productivity premium" compared to purely domestic firms (Criscuolo, Martin 2009). This ties in with the literature on firm heterogeneity (Helpman et al. 2004) which shows that a firm's status in terms of global engagement is crucially related to the firm's performance. In this context, FMNEs may have a higher probability of survival because on the one hand foreign capital participation may itself be signalling unobserved quality of the affiliate firm (cherry-picking hypothesis), and/or on the other, it may be a vehicle for access to more advanced foreign technologies and, therefore for improving firm efficiency. Similarly, we can argue that DMNEs should exhibit better survival dynamics compared

\footnotetext{
${ }^{1}$ It should be noted that the literature review included in this study is not exhaustive, but is limited to the research studies that we consider relevant to the purpose of our paper.
} 
to domestic non MNEs, because only the more productive firms are able to become multinationals (self-selection effect), and/or investing abroad improves firm efficiency (learning effect).

Empirically, a first group of studies has compared "foreign-owned" and "domestic firms" survival rates. The findings are ambiguous. In most of these studies - after controlling for firm and industry differences - FMNEs are found to be more footloose than domestic firms (see, among others, Colombo, Delmastro 2000 for Italy; Bernard, Sjöholm 2003 for Indonesia; Görg, Strobl 2003 for Ireland; Girma, Görg 2004 for UK; Alvarez, Görg 2009 for Chile), while in other studies they are found to have the same chances of survival as domestic firms (Mata, Portugal 2002 for Portugal; Ozler, Taymaz 2007 for Turkey, Blanchard et al. 2012 for Belgium; Godart et al. 2012 for Ireland). Only Gibson, Harris (1996) have found that, for New Zealand, foreign firms are less likely to exit than domestic firms, but their result was probably influenced by the increasing trade liberalisation taking place over the period analysed.

A second group of studies has focused on comparing domestic multinational and nonmultinational survival behaviour. Bernard and Jensen (2007) and Giovannetti et al. (2009), controlling for plant (firm) and industry attributes, find respectively that US and Italian multinationals exhibit higher failure risks. Using longitudinal panel data on Japanese firms, Kimura and Kiyota (2006) find that overseas investment has a negative impact on firm survival.

Finally, literature comparing all three firms' categories is emerging but is still limited (Kimura, Fujii 2003; Van Beveren 2007; Inui et al. 2009; Bandick 2010; Ferragina et al. 2010; Amendola et al. 2012), and also reveals mixed results. Kimura and Fujii (2003) show that foreign shareholders do not exhibit a footloose behaviour while Japanese firms, if small and globally committed via FDI, appear less likely to survive. Inui et al. (2009) find that foreign ownership raises plant exit rates but the effect is only weakly significant, while Japanese multinationals are much more likely to shut down plants. Bandick (2010) further suggests that FMNEs and export active plants have higher survival rates than both domestic non-exporting firms and DMNEs. Only Van Beveren (2007) finds that foreign multinationals are more likely to shut down operations compared to national firms and to DMNEs both in manufacturing and in service sectors.

\section{Data description and preliminary facts}

The data employed in this paper are drawn from AIDA database (Analisi Informatizzata Delle Aziende) provided by Bureau Van Dijk. AIDA collects annual accounts of Italian corporate enterprises and contains information on a wide set of economic and financial variables such as sales, costs and number of employees, value added, tangible fixed assets, start-up year, sector of activity, as well as legal and ownership status.

In the database, the legal status (i.e. active, into liquidation, inactive) enables us to easily identify the exit of the firm, year by year. Specifically, a firm is defined to exit in year $t$ when this is the last year of operation (i.e. firm characterised by permanent closure, firm in liquidation and each firm acquired by another firm). 
The information on ownership status included in the dataset allowed us to separate Italian firms into:

- Domestic Multinational Enterprises (DMNEs): non foreign-owned firms with a share of direct ownership greater/equal to 10 percent in firms located in countries other than Italy.

- Foreign Multinational Enterprises (FMNEs): Italian firms whose Global Ultimate owner is foreign.

- Non - Multinational Enterprises (NMNEs): Italian non-multinational firms.

The information used covers the years 2004-2008. By omitting all observations for which the necessary data are incomplete, we obtained an unbalanced panel of about 900 thousand observations.

The advantage of using this dataset is twofold. Firstly, it is highly representative of the entire universe of corporate companies: in 2007, our sample covers about 87 percent of total employees declared by the Italian National Institute of Statistics. Secondly, our dataset reflects quite well the actual size distribution of firms in the Italian economy characterised, as is well known, by a large weight of small and medium-sized enterprises (around 95 percent of firms present in our database have less than fifty employees, close to the official statistics of 98.5 percent in 2006 for the entire universe). This is a very important aspect in the analysis of duration, as the over-sampling of large firms underestimates the real number of movements in an economy, since entry and exit are typically a small-sized firm phenomenon.

Before formally testing for the relationship between ownership and firm survival, we provide some descriptive statistics based on our data.

Table 1 compares the distribution of Italian firms by ownership status, sector of activity (manufacturing and services) and size (small, medium and large firms), the latter measured by the number of employees. According to the figures, NMNEs represent the largest percentage of Italian firms, and are mainly of smaller size, while the shares of FMNEs and DMNEs are very small. These figures are very close to those provided by ISTAT, according to which in 2007 about $0.3 \%$ of Italian firms was foreign-owned. The discrepancy occurs because our sample is restricted to corporate companies. It would also appear that DMNEs are mainly of small size in services and of medium size in manufacturing.

Table 2 reports the average exit rate of firms (measured by the number of exiting firms relative to the total number of firms), both for all firms and according to the ownership status. The exit rates for all sectors and services suggest that the percentage of exit is larger in NMNEs with a rate of 6 and 6.50 percent. Conversely, in manufacturing sectors, FMNEs present the higher exit rate with a percentage of 5.83. Our sample is also representative with regard to the exit rate, reflecting the average exit rate registered by official national sources of 7.5 percent for total Italian firms. 
Table 1. Distribution of Italian firms by size and ownership status (percentages, sample average)**

\begin{tabular}{llcccc}
\hline & & Small firms & Medium firms & Large firms & Total \\
\hline \multirow{4}{*}{ Total sample } & FMNEs & 61.08 & 27.30 & 11.62 & 0.60 \\
\cline { 2 - 6 } & DMNEs & 33.66 & 48.11 & 18.23 & 0.65 \\
\cline { 2 - 6 } & NMNEs & 94.99 & 4.45 & 0.56 & 98.76 \\
\cline { 2 - 6 } & All firms & 94.39 & 4.87 & 0.74 & 100.00 \\
\hline \multirow{3}{*}{$\begin{array}{l}\text { Manufacturing } \\
\text { sector }\end{array}$} & FMNEs & 45.95 & 37.48 & 16.57 & 0.76 \\
\cline { 2 - 6 } & DMNEs & 20.34 & 59.32 & 20.34 & 1.31 \\
\cline { 2 - 6 } & NMNEs & 92.10 & 7.33 & 0.57 & 97.93 \\
\cline { 2 - 6 } & All firms & 90.80 & 8.24 & 0.95 & 100.00 \\
\cline { 2 - 6 } Service sectors & FMNEs & 71.03 & 20.60 & 8.37 & 0.52 \\
\cline { 2 - 6 } & DMNEs & 56.78 & 28.65 & 14.57 & 0.34 \\
\cline { 2 - 6 } & NMNEs & 96.29 & 3.16 & 0.56 & 99.13 \\
\cline { 2 - 6 } & All firms & 96.02 & 3.34 & 0.64 & 100.00 \\
\cline { 2 - 6 } & & &
\end{tabular}

Note: **Small firms (1-49 employees); medium firms (50-249); large firms (more than 250 employees). Source: author's elaborations on AIDA database.

Table 2. Average exit rate by ownership status and sector (percentages)

\begin{tabular}{lccc}
\hline & All sectors & Manufacturing sectors & Services \\
\hline All firms & 6.00 & 4.74 & 6.50 \\
\hline FMNEs & 5.80 & 5.83 & 5.80 \\
\hline DMNEs & 3.30 & 3.41 & 3.20 \\
\hline NMNEs & 6.00 & 4.75 & 6.50 \\
\hline
\end{tabular}

Source: author's elaborations on AIDA database.

\section{Empirical methodology}

The focus of our work is to examine whether foreign multinationality on the one hand, and domestic multinationality on the other, are significant for domestic firms' probability of survival.

We start by using non-parametric methods such as the Kaplan-Meier's to estimate the probability of survival up to a certain age and to compare survival patterns across the three different groups of firms: NMNEs, FMNEs and DMNEs. We are interested in the probability that the period of survival is of at least length $t$. This probability is given by the survival function that is defined as:

$$
S(t)=1-F(t)=\operatorname{Pr}(T \geq t),
$$

where $\mathrm{T}$ represents a random variable and $\mathrm{F}(\mathrm{t})$ is the cumulative probability distribution of $\mathrm{T}$. 
The most commonly used non-parametric estimate of the survival function is the Kaplan-Meier estimator which is given by:

$$
S(t)=\prod_{j \mid t_{j} \leq t}\left(\frac{n_{j}-d_{j}}{n_{j}}\right),
$$

where $\mathrm{S}(t)$ denotes the probability of surviving up to age $t$-defined as the difference between year $t$ and the official year of incorporation of the firm - whereas the failure event is identified as the interruption of firm's activities ${ }^{2}-, n_{j}$ is the number of firms that have survived up to $t_{j}$ years of age and $d_{j}$ is the number of firms that die at age $t_{j}$. From Figure 1 and with regard to the total sample, we observe different survival patterns between domestic and foreign MNEs compared to purely domestic firms. In particular, both FMNEs and DMNEs endure better survival prospects: 72 percent of domestic non-MNEs survive more than 30 years, whereas the same probability of survival is 78 percent for foreign-owned firms and 87 for domestic MNEs. A similar result was found at firm level by Van Beveren (2007) and also at plant level by Bernard and Sjöholm (2003), Görg and Strobl (2003) and Ozler and Taymaz (2007). However, Bandick (2010) found that MNEs, both foreign and domestic, were less likely to survive than Swedish owned non-MNE domestic plants. This picture is also confirmed with regard to services (Fig. 3). Less clear-cut is the evidence for the manufacturing sector (Fig. 2). In order to check for the significance of the differences in survival functions across the three groups of firms, we run log-rank non-parametric tests of homogeneity. The results for all sectors, reported in Table 3, confirm the existence of remarkable differences in the survival prospects among the three groups of firms.

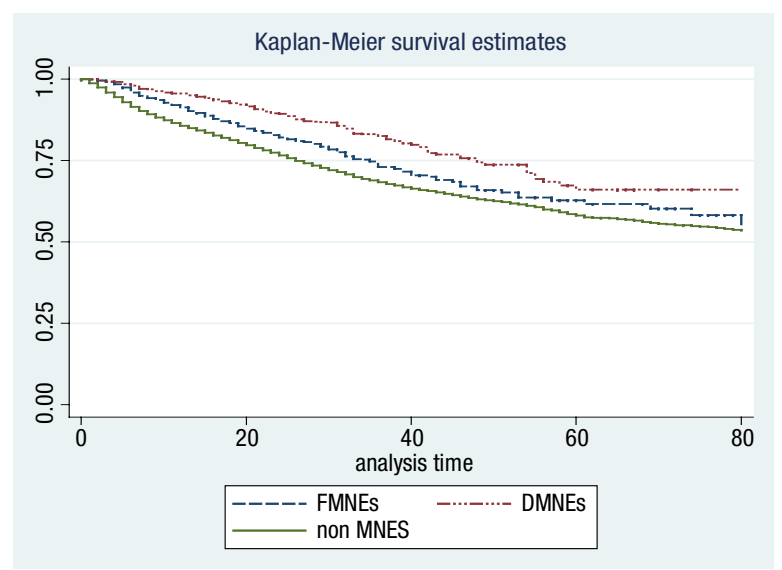

Fig. 1. Kaplan-Meier survival functions by nationality of ownership

Note: Survival probability on the vertical axis. Analysis time represents firms' age.

\footnotetext{
${ }^{2}$ The effect of age on the hazard rate is incorporated into the model since duration is a function of the firm's age.
} 


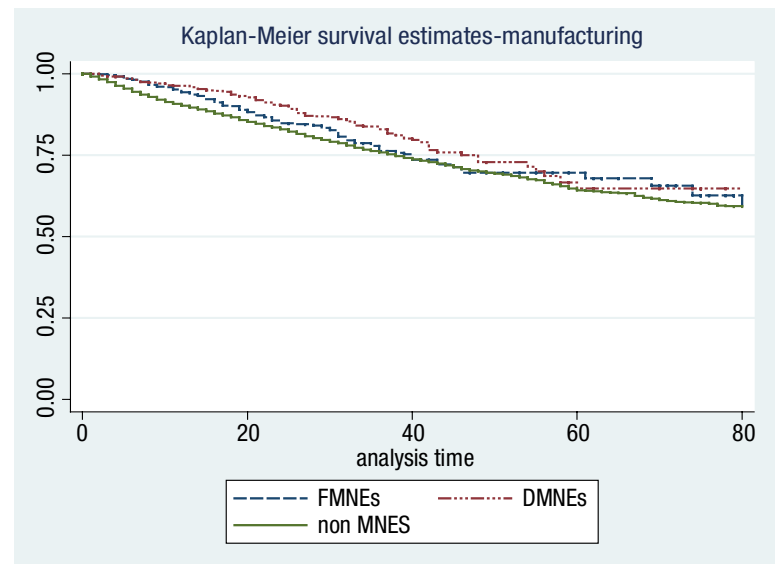

Fig. 2. Kaplan-Meier survival functions by nationality of ownership (manufacturing) Note: Survival probability on the vertical axis. Analysis time represents firms' age.

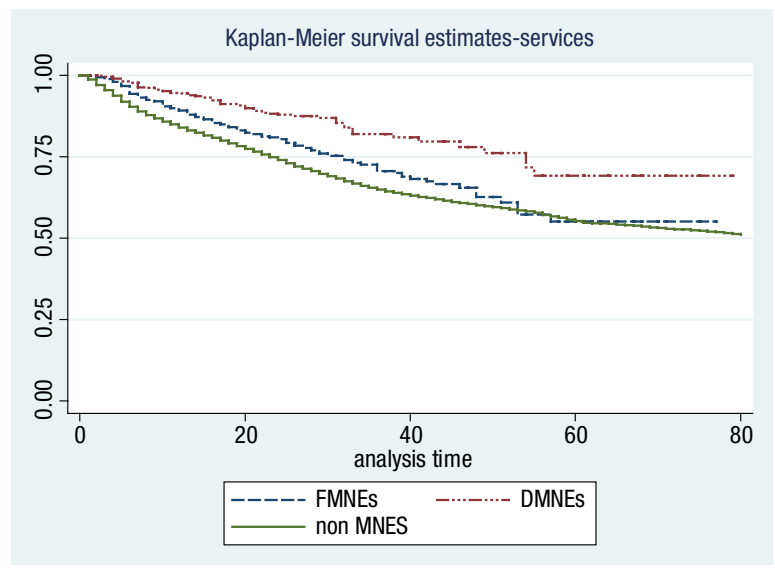

Fig. 3. Kaplan-Meier survival functions by nationality of ownership (services)

Note: Survival probability on the vertical axis. Analysis time represents firms' age.

Table 3. Log-rank tests for the equality of the survival functions by ownership status

\begin{tabular}{lccc}
\hline & $\begin{array}{c}\text { Foreign-owned versus } \\
\text { domestic MNEs }\end{array}$ & $\begin{array}{c}\text { Foreign-owned versus } \\
\text { domestic firms }\end{array}$ & $\begin{array}{c}\text { Domestic MNEs versus } \\
\text { domestic firms }\end{array}$ \\
\hline All sectors & $31.0^{* * *}$ & $35.7^{* * *}$ & $136.9^{* * *}$ \\
\hline Manufacturing & $4.8^{* *}$ & $2.9^{*}$ & $21.6^{* * *}$ \\
\hline Services & $19.9^{* * *}$ & $15.6^{* * *}$ & $60.9^{* * *}$ \\
\hline
\end{tabular}

Notes: The null hypothesis is that groups of firms survival functions are equal. This statistic distributes as a chi square with $r-1$ degrees of freedom. 
However, it is well known that a severe limitation of Kaplan-Meier survival functions is that such analysis does not consider other factors that may affect firm survival. In order to properly control for other characteristics associated with the survival probabilities, we turn to a multivariate analysis based on the following hazards model where the hazard function $[\lambda(t)]$ of a firm $i$ - i.e., the rate at which firms exit at age $t$ given that they have survived up to age $t-1-$ is given by:

$$
\lambda(t)=\lambda_{0}(t) H\left(\beta^{\prime} x\right)
$$

In equation (3), the hazard function depends multiplicatively on the vector of explanatory variables (which measure firm and industry specific characteristics affecting firm survivability) with the corresponding vector of regression coefficients to be estimated and the (arbitrary and unspecified) baseline hazard, $\lambda_{0}(t)$, which is the hazard corresponding to $H\left(\beta^{\prime} x_{i}\right)=1$.

Following Cox, the functional form adopted to specify the effect of the covariates on the base hazard is the exponential one. So, the hazard a firm $i$ faces may be written in the following form:

$$
\lambda_{i}(t)=\lambda_{0}(t) \exp \left(\beta^{\prime} x_{i}\right)
$$

In equation (4), $\beta=1$ means that the covariates do not affect the hazard ratio; a coefficient of $\beta>1$ implies that the variable increases the risk of exit, while a value of $\beta<$ 1 reduces the hazard of failure or increases survival time.

Equation (4) is the proportional hazard model, and its logarithmic expression gives us a linear model that can be estimated by maximum likelihood method:

$$
\ln \lambda_{i}(t)=\ln \lambda_{0}(t)+\beta^{\prime} x_{i}
$$

Following both the leading theoretical and empirical literature on firm survival, we use in our model the set of explanatory variables shown in Table 4, distinguishing firm and industry level variables. All financial variables were converted into constant 2000 euro, using 3-digit industry price level deflators.

Table 4. Definition of variables, data sources and expected relationships

\begin{tabular}{lllc}
\hline \multicolumn{1}{c}{ Description } & Source & Expected sign \\
\hline SIZE* & \multicolumn{1}{c}{ Firm-specific variables } & \\
\hline TFP** & $\begin{array}{l}\text { Total Factor Productivity measured by the residuals } \\
\text { from a Cobb-Douglas production function estimated } \\
\text { separately for each Ateco 3-digit industry }\end{array}$ & Aida & - \\
\hline TECH & $\begin{array}{l}\text { R\&D intensity defined as the ratio of R\&D } \\
\text { expenditure to sales }\end{array}$ & Aida & - \\
\hline PCM & $\begin{array}{l}\text { Firm's margin price-cost ratio constructed as total } \\
\text { sales minus the variable costs of production (labour } \\
\text { cost and intermediate consumer goods) divided by } \\
\text { the total sales }\end{array}$ & Aida & + - \\
& & & \\
\hline
\end{tabular}


End of Table 4

\begin{tabular}{|c|c|c|c|}
\hline & Description & Source & Expected sign \\
\hline \multicolumn{4}{|c|}{ Firm-specific variables } \\
\hline WAGE & Firms' average wages & Aida & - \\
\hline OUT & $\begin{array}{l}\text { Domestic multinational ownership dummy that takes } \\
\text { on the value } 1 \text { if the firm is an Italian owned-MNE, } \\
0 \text { otherwise }\end{array}$ & Aida & $+/-$ \\
\hline INW & $\begin{array}{l}\text { Foreign ownership dummy that takes on the value } 1 \\
\text { if the firm is foreign-owned, } 0 \text { otherwise }\end{array}$ & Aida & $+/-$ \\
\hline \multicolumn{4}{|c|}{ Industry-specific variables } \\
\hline HERF & $\begin{array}{l}\text { Herfindahl concentration ratio at industry level } \\
\text { (3-digit Ateco) }\end{array}$ & Aida & $+/-$ \\
\hline MES & $\begin{array}{l}\text { Minimum Efficient Scale of the industry, measured } \\
\text { as the mean size of the largest firms in each industry } \\
\text { accounting for one-half of the industry sales (3-digit } \\
\text { Ateco) (Comanor \& Wilson, 1967) }\end{array}$ & Aida & $+/-$ \\
\hline GROWTH & 3-digit Ateco industry growth rate of sales & Aida & - \\
\hline KL & $\begin{array}{l}\text { Overall capital intensity given by the ratio of fixed } \\
\text { assets on number of employees at the industry } \\
\text { (3-digit Ateco) level }\end{array}$ & Aida & - \\
\hline FP & $\begin{array}{l}\text { Foreign penetration defined as the share of foreign } \\
\text { employment in a given sector }\end{array}$ & Aida & - \\
\hline IMPCOMP & $\begin{array}{l}\text { Import penetration ratio measured by the ratio } \\
\text { between imports and apparent consumption at } \\
\text { industry (3-digit Ateco) level }\end{array}$ & Istat & + \\
\hline
\end{tabular}

Notes: * Firms are classified in several groups: lower than 20 employees (size 1), between 20 and 50 employees (size 2), between 50 and 100 employees (size 3) and more than 100 employees (size 4). In all models, size 1 firms are the reference group; ** The Levinsohn and Petrin (2003) estimation method was adopted: intermediate inputs were used as instruments to deal with the potential simultaneity problem in estimating firm level production functions.

\section{Estimation results}

Our empirical strategy controls for heterogeneity among firms by including in our model the variables described in Table 4, which measure the relevant characteristics that are expected to affect firm survival in the Italian economy. Two binary variables will enable us to discriminate the effect of being FMNEs or DMNEs. We run separate regressions for manufacturing and service(s) sectors in order to determine whether the multinationality, both foreign and domestic, responds in different ways in these two sectors to a given set of factors. For all the different sector aggregations, we present two different specifications of the model: the first considers only covariates at firm level; the second also inserts industry level variables. 
Simple correlation coefficients have been calculated among the variables in order to assess whether multicollinearity is present. Correlations between the independent variables are generally low ${ }^{3}$. Table 5 provides the regression results of the Cox proportional hazard model of equation (4) applied to our sample of Italian firms over our period of analysis. All estimations are stratified by 2-digit (Ateco) industry classification, which allows for equal coefficients of the covariates across strata (industries), but baseline hazards unique for each stratum (industry). The first two columns show the results of the basic and extended model applied to the overall economy (Ateco 15-99), while columns 3 to 6 display the results of these two models for manufacturing and services, respectively. For each regression, we report coefficients and associated robust standard errors, adjusted for clustering at the firm level. Wald tests provide satisfactory support for our model specification.

Overall, we have almost 900 thousand observations corresponding to approximately 370 thousand firms $(99,840$ in manufacturing and 269,612 in services) of which almost 45,000 fail during the five-year observation period (10,610 in manufacturing and 34,382 in services).

In order to interpret the magnitude of these effects, it is useful to calculate the hazard ratio of the coefficients in Table 5 by taking the exponential. For a dummy variable, the hazard ratio represents the increase in the overall hazard rate facing the firm when the corresponding dummy is equal to one. For a non binary variable, the hazard ratio represents the increase in the overall hazard rate facing the firm when the corresponding variable increases. Negative (positive) coefficients correspond to risk ratios lower (higher) than one, and imply that the hazard rate decreases (increases) while the corresponding probability of survival increases (decreases).

The first remarkable result is that, unlike the unconditional analysis, we find that foreign firms have significantly higher probability of exit in all models and sectors considered. Focusing on the extended model results, we observe that being controlled by a foreign firm enhances the hazard rates of a firm 1.6 and 1.4 times in manufacturing and services respectively. This result lends support to the hypothesis that foreign MNEs are more "footloose" than purely domestic firms, and is in line with the findings of a wide range of literature (see e.g., Audretsch, Mahmood 1995; Bernard, Sjöholm 2003; Görg, Strobl 2003; Van Beveren 2007).

Conversely, the results for the domestic-owned multinationals (OUT) are less clear-cut. While the DMNEs in manufacturing do not show a hazard rate significantly different from the rest of the sample, in services the hazard ratio indicates that the probability of exit for domestic MNEs operating in this sector is 24 percent lower than that of NMNEs. This result is in line with Van Beveren (2007) but differs from Kimura and Fujii (2003), Bandick (2010), Inui et al. (2009), Bernard and Jensen (2007) and Giovannetti et al. (2009).

We also observe that compared to exiters, surviving firms are larger, regardless of the sector of activity. This result is consistent with most of the empirical evidence obtained

\footnotetext{
${ }^{3}$ Results are available upon request.
} 
Table 5. Estimation results: Cox Proportional Hazard Model

\begin{tabular}{|c|c|c|c|c|c|c|}
\hline & \multicolumn{2}{|c|}{ Overall } & \multicolumn{2}{|c|}{ Manufacturing } & \multicolumn{2}{|c|}{ Services } \\
\hline & (1) & (2) & (3) & (4) & (5) & (6) \\
\hline \multicolumn{7}{|c|}{ Firm variables } \\
\hline INW & $\begin{array}{c}0.395 \\
(0.065)^{* * *} \\
\end{array}$ & $\begin{array}{c}0.370 \\
(0.070) * * * \\
\end{array}$ & $\begin{array}{c}0.544 \\
(0.123) * * * \\
\end{array}$ & $\begin{array}{c}0.497 \\
(0.135) * * * \\
\end{array}$ & $\begin{array}{c}0.334 \\
(0.080) * * * \\
\end{array}$ & $\begin{array}{c}0.307 \\
(0.084) * * * \\
\end{array}$ \\
\hline OUT & $\begin{array}{l}-0.119 \\
(0.082)\end{array}$ & $\begin{array}{l}-0.104 \\
(0.087)\end{array}$ & $\begin{array}{c}0.072 \\
(0.106)\end{array}$ & $\begin{array}{c}0.048 \\
(0.113)\end{array}$ & $\begin{array}{c}-0.345 \\
(0.135) * *\end{array}$ & $\begin{array}{c}-0.279 \\
(0.143) * *\end{array}$ \\
\hline SIZE 2 & $\begin{array}{c}-0.267 \\
(0.019) * * * \\
\end{array}$ & $\begin{array}{c}-0.238 \\
(0.021) * * *\end{array}$ & $\begin{array}{c}-0.398 \\
(0.033) * * * \\
\end{array}$ & $\begin{array}{c}-0.397 \\
(0.036) * * * \\
\end{array}$ & $\begin{array}{c}-0.191 \\
(0.023)^{* * *}\end{array}$ & $\begin{array}{c}-0.146 \\
(0.026) * * *\end{array}$ \\
\hline SIZE 3 & $\begin{array}{c}-0.305 \\
(0.033) * * * \\
\end{array}$ & $\begin{array}{c}-0.293 \\
(0.037) * * * \\
\end{array}$ & $\begin{array}{c}-0.402 \\
(0.053) * * * \\
\end{array}$ & $\begin{array}{c}-0.445 \\
(0.058) * * * \\
\end{array}$ & $\begin{array}{c}-0.242 \\
(0.042) * * *\end{array}$ & $\begin{array}{c}-0.196 \\
(0.048) * * * \\
\end{array}$ \\
\hline SIZE 4 & $\begin{array}{c}-0.219 \\
(0.038) * * *\end{array}$ & $\begin{array}{c}-0.181 \\
(0.042) * * *\end{array}$ & $\begin{array}{c}-0.190 \\
(0.066) * * *\end{array}$ & $\begin{array}{c}-0.243 \\
(0.075) * * * \\
\end{array}$ & $\begin{array}{c}-0.239 \\
(0.047) * * * \\
\end{array}$ & $\begin{array}{c}-0.177 \\
(0.053) * * *\end{array}$ \\
\hline TECH & $\begin{array}{c}-0.053 \\
(0.028)^{*}\end{array}$ & $\begin{array}{l}-0.067 \\
(0.030) \\
\end{array}$ & $\begin{array}{l}-0.039 \\
(0.046) \\
\end{array}$ & $\begin{array}{l}-0.019 \\
(0.049) \\
\end{array}$ & $\begin{array}{l}-0.049 \\
(0.035) \\
\end{array}$ & $\begin{array}{c}-0.077 \\
(0.038) * *\end{array}$ \\
\hline TFP & $\begin{array}{c}-0.002 \\
(0.000) * * *\end{array}$ & $\begin{array}{c}-0.002 \\
(0.001) * * *\end{array}$ & $\begin{array}{c}-0.004 \\
(0.001) * * *\end{array}$ & $\begin{array}{c}-0.005 \\
(0.001) * * *\end{array}$ & $\begin{array}{c}-0.002 \\
(0.001)^{* * *}\end{array}$ & $\begin{array}{c}-0.002 \\
(0.000) * * *\end{array}$ \\
\hline PCM & $\begin{array}{c}-0.115 \\
(0.026) * * *\end{array}$ & $\begin{array}{c}-0.010 \\
(0.029) * *\end{array}$ & $\begin{array}{c}0.148 \\
(0.068) * * * \\
\end{array}$ & $\begin{array}{c}0.189 \\
(0.074) * * \\
\end{array}$ & $\begin{array}{c}-0.158 \\
(0.029) * * *\end{array}$ & $\begin{array}{l}-0.035 \\
(0.031) \\
\end{array}$ \\
\hline WAGE & $\begin{array}{c}0.0014 \\
(0.0010) \\
\end{array}$ & $\begin{array}{c}0.0005 \\
(0.0002) * * * \\
\end{array}$ & $\begin{array}{c}0.0011 \\
(0.0004) * * * \\
\end{array}$ & $\begin{array}{c}0.001 \\
(0.000) * * * \\
\end{array}$ & $\begin{array}{c}0.001 \\
(0.002) \\
\end{array}$ & $\begin{array}{c}0.001 \\
(0.001) \\
\end{array}$ \\
\hline \multicolumn{7}{|c|}{ Industry variables } \\
\hline IMPCOMP & & $\begin{array}{c}-0.156 \\
(0.035) * * *\end{array}$ & & $\begin{array}{l}-0.062 \\
(0.042) \\
\end{array}$ & & $\begin{array}{c}-0.379 \\
(0.090) * * * \\
\end{array}$ \\
\hline KL & & $\begin{array}{c}-0.001 \\
(0.000) * * *\end{array}$ & & $\begin{array}{c}-0.004 \\
(0.001) * * * \\
\end{array}$ & & $\begin{array}{c}-0.001 \\
(0.000) * * *\end{array}$ \\
\hline MES & & $\begin{array}{c}0.001 \\
(0.000) * *\end{array}$ & & $\begin{array}{c}0.0010 \\
(0.0003)^{* * *} \\
\end{array}$ & & $\begin{array}{c}0.001 \\
(0.000)\end{array}$ \\
\hline HERF & & $\begin{array}{c}0.316 \\
(0.146)\end{array}$ & & $\begin{array}{c}-0.900 \\
(0.533) *\end{array}$ & & $\begin{array}{c}0.414 \\
(0.153) * * * \\
\end{array}$ \\
\hline GROWTH & & $\begin{array}{l}-0.145 \\
(0.086) \\
\end{array}$ & & $\begin{array}{c}0.145 \\
(0.085) \\
\end{array}$ & & $\begin{array}{c}-0.218 \\
(0.100) * *\end{array}$ \\
\hline FP & & $\begin{array}{c}-0.564 \\
(0.156) * * *\end{array}$ & & $\begin{array}{c}0.242 \\
(0.362) \\
\end{array}$ & & $\begin{array}{c}-0.708 \\
(0.177) * * * \\
\end{array}$ \\
\hline $\begin{array}{l}\text { Industry } \\
\text { dummies }\end{array}$ & Yes & Yes & Yes & Yes & Yes & Yes \\
\hline Time dummies & Yes & Yes & Yes & Yes & Yes & Yes \\
\hline$N^{\circ}$ of obs. & 881358 & 728715 & 254153 & 217410 & 627705 & 511305 \\
\hline$N^{\circ}$ of subjects & 369113 & 306759 & 99840 & 85677 & 269612 & 221342 \\
\hline$N^{\circ}$ of failures & 44992 & 37289 & 10610 & 9119 & 34382 & 28170 \\
\hline Wald's test $\left(\chi^{2}\right)$ & 442.36 & 379.14 & 276.81 & 287.21 & 231.71 & 188.55 \\
\hline Log-likelihood & -217511.14 & -183716.69 & -40893 & -33389.451 & -176570.9 & -150259.85 \\
\hline
\end{tabular}

Notes: $* * *, * * *$ indicate statistical significance at the 1,5 and 10 percent levels. Standard errors, adjusted for clustering at the firm level, are in parentheses. 
by the literature concerning the liability of smallness (Audretsch, Mahmood 1995; Dunne et al. 1988; Mata, Portugal 1994; Esteve Pérez, Sanchis Lilopis 2004; Esteve Pérez, Mañez Castillejo 2008). Several reasons could suggest a negative relationship between firm size and the probability of exit. First, larger firms are more likely to have output levels close to their industry minimum efficient scale. Moreover, compared to small firms, large firms could also have an enhanced chance of survival given their easier access to capital market and better possibility of recruiting qualified workers. To account for a possible non-linear effect, we also included a set of dummy variables distinguishing different size classes. Like previous studies (Strotmann 2007; Esteve Pérez, Mañez Castillejo 2008) we find evidence of a non-linear effect.

Our results also clearly indicate, in line with several theoretical (Jovanovic 1982; Hopenhayn 1992) and empirical studies (Esteve Pérez, Mañez Castillejo 2008; Van Beveren 2007; Bandick 2010), that the probability of survival is mainly motivated by productivity differences at the firm level.

We also find that investing in R\&D weakly increases the probability of survival of firms in the service sector $(+8 \%)$ while it is not significant in manufacturing. A negative impact of R\&D in the manufacturing sector was found by Giovannetti et al. (2009) while Kimura and Fujii (2003), Esteve Pérez et al. (2004), Esteve Pérez and Mañez Castillejo (2008), found a positive effect. A possible explanation for our result is that $\mathrm{R} \& \mathrm{D}$ represents a special investment which develops firm's capabilities and improves competitiveness, but also represents a heavy financial burden especially for small Italian firms. A higher profit margin (PCM) turns out to reduce the hazard ratio in the service sector (although it is only significant in the basic model), but surprisingly tends to increase the risk of failure by more than 21 percent in the manufacturing sector. The explanation for our result may be twofold. On the one hand, if profit margins are higher, firm activities tend on average to be more risky; on the other hand, firms with higher profit margins more easily become a target for acquisitions. An increase in failure risk is also shown by firms that pay higher wages in manufacturing. This result is in line with the hypothesis that firms are relatively less competitive if they pay higher wages for given productivity levels.

Looking at the industry-specific factors, our results show that capital intensity positively affects the likelihood of survival, irrespective of the sectors. This can be explained by the argument that, in industries with high capital requirements, firms are more committed to their resources, i.e. capital intensity being a sunk cost acts as a barrier to exit (Audretsch, Mahmood 1995). Furthermore, firms in manufacturing sectors where economies of scale are relevant face a higher exit risk. whereas a higher degree of concentration measured by the Herfindahl concentration index decreases the exit rate in manufacturing, but increases it in services. In this regard, our results are very close to Görg and Strobl (2003) and Audretsch (1995), who pointed out that firms in sectors with a high MES level face a higher chance of exit, because they may find it more difficult to achieve an efficient production scale and suffer a cost-disadvantage vis-à-vis the most efficient firms in the market. With regard to the effect of market concentration on firm survival, the theory is not clear-cut. On the one hand, in concentrated industries, many 
firms may be protected by competition and, as a result, the likelihood of firm closure will be reduced. On the other hand, firms in highly concentrated markets may face aggressive behaviour from rivals and, as a consequence, have a higher possibility of exit.

Empirical evidence regarding the effect of market concentration on firm survival also produced mixed results: Görg and Strobl (2003) found a positive impact while Mata and Portugal (1994) and Strotmann (2007) found a negative one. Firms in import-competing industries have a chance of survival 32 percent higher in services, while the coefficient although negative is not significant in manufacturing. Industry growth also reduces the risk of failure but only in services: firms operating in fast-growing industries have a likelihood of survival 20 percent higher. In many studies, fast-growing industries were found to induce lower exit rates than slowly growing or declining industries, since the better the demand side-conditions are, the higher is the chance of survival (Audretsch 1995; Dunne et al. 1988; Mata, Portugal 1994, 2004; Görg, Strobl 2003). Finally, the presence of foreign firms reduces hazard ratios in the service sector by a high percentage (51\%), suggesting that the presence of FDI generates positive spillover effects.

Our results are consistent with the literature that tested the impact of foreign presence on domestic firms' survival (Görg, Strobl 2005; Ozler, Taymaz 2007; Bandick 2010), but in contrast with some studies which have found that a greater presence of foreign affiliates may generate competition effects that increase the probability of exit of all firms (De Backer, Sleuwaegen 2003), or alternatively of firms located in specific sectors (Görg, Strobl 2005; Burke et al. 2008). However, the literature on FDI spillovers in Italy generally points to a weak presence of spillovers from FDI in manufacturing (Imbriani, Reganati 2002; Reganati, Sica 2007; Castellani, Zanfei 2007), while finding a significant impact in services (Pittiglio et al. 2008).

\subsection{Estimation results for sectors with different technological intensity}

Due to the large size of our database, we are able to better verify the existence of some sector-specific characteristics that may interact with the different covariates in explaining the probability of firm survival in the Italian economy. Thus, we re-estimate our model by disaggregating manufacturing and service sectors according to the level of technological intensity. Following the OECD taxonomy, we aggregate our manufacturing (service) sectors into two groupings: i) high and medium-high technology (knowledge-intensive) industries and ii) low and medium-low technology (less-knowledge-intensive).

The estimates in Tables 6 reveal that being controlled by a FMNE increases the hazard rate of a firm, regardless of the technological level of the sector of activity in which it operates. Thus, within both static and dynamic industries, foreign ownership exerts a strongly negative influence on the survival of firms by increasing the chance of exit; this result suggests that the behaviour and strategies of MNEs differ from those of domestic non-multinational firms. In the low and medium-low technology manufacturing sectors, the chances of exit for FMNEs increase by approximately 66 percent compared to non-MNEs; in the high and medium-high technology manufacturing industries, the chance of exit increases by approximately 47 percent. The same result is obtained in 
the service sector: FMNEs belonging to the less-knowledge-intensive services have a 41 percent greater risk of exiting compared with NMNEs belonging to the same sector, and exceed by 39 percent the exit risk of domestic non-multinational firms within knowledge-intensive services.

Table 6. Estimation results by knowledge intensity in the manufacturing and service sectors: Cox Proportional Hazard Model

\begin{tabular}{|c|c|c|c|c|}
\hline & \multicolumn{2}{|c|}{ Manufacturing } & \multicolumn{2}{|c|}{ Services } \\
\hline & $\begin{array}{l}\text { Low and medium- } \\
\text { low technology }\end{array}$ & $\begin{array}{l}\text { High and medium- } \\
\text { high technology }\end{array}$ & $\begin{array}{l}\text { Less-knowledge- } \\
\text { intensive services }\end{array}$ & $\begin{array}{l}\text { Knowledge- } \\
\text { intensive services }\end{array}$ \\
\hline & (i) & (ii) & (iii) & (iv) \\
\hline & 1 & 2 & 3 & 4 \\
\hline \multicolumn{5}{|c|}{ Firm variables } \\
\hline INW & $\begin{array}{c}0.5113 \\
(0.0976)^{* * *}\end{array}$ & $\begin{array}{c}0.3858 \\
(0.0602)^{* * *}\end{array}$ & $\begin{array}{c}0.3294 \\
(0.1466)^{* *}\end{array}$ & $\begin{array}{c}0.3437 \\
(0.1090)^{* * *}\end{array}$ \\
\hline OUT & $\begin{array}{c}0.0935 \\
(0.1453)\end{array}$ & $\begin{array}{l}-0.0439 \\
(0.1684)\end{array}$ & $\begin{array}{c}-0.4918 \\
(0.2406)^{* *}\end{array}$ & $\begin{array}{l}-0.2761 \\
(0.2055)\end{array}$ \\
\hline SIZE 2 & $\begin{array}{c}-0.4433 \\
(0.0432)^{* * *}\end{array}$ & $\begin{array}{c}-0.3698 \\
(0.0609)^{* * *}\end{array}$ & $\begin{array}{c}-0.1166 \\
(0.0392)^{* * *}\end{array}$ & $\begin{array}{c}-0.1132 \\
(0.0480)^{* *}\end{array}$ \\
\hline SIZE 3 & $\begin{array}{c}-0.4507 \\
(0.0698)^{* * *}\end{array}$ & $\begin{array}{c}-0.4704 \\
(0.0999)^{* * *}\end{array}$ & $\begin{array}{l}-0.0666 \\
(0.0682)\end{array}$ & $\begin{array}{c}-0.3052 \\
(0.0855)^{* * *}\end{array}$ \\
\hline SIZE 4 & $\begin{array}{c}-0.3629 \\
(0.0915)^{* * *}\end{array}$ & $\begin{array}{l}-0.1138 \\
(0.1093)\end{array}$ & $\begin{array}{c}0.0351 \\
(0.0762) \\
\end{array}$ & $\begin{array}{c}-0.3378 \\
(0.0881)^{* * *}\end{array}$ \\
\hline TECH & $\begin{array}{c}0.0769 \\
(0.0595)\end{array}$ & $\begin{array}{c}-0.1440 \\
(0.0789)^{*}\end{array}$ & $\begin{array}{l}-0.06080 \\
(0.0597)\end{array}$ & $\begin{array}{l}-0.0305 \\
(0.0703)\end{array}$ \\
\hline TFP & $\begin{array}{c}-0.0084 \\
(0.0021)^{* * *} \\
\end{array}$ & $\begin{array}{c}-0.0038 \\
(0.0013)^{* *}\end{array}$ & $\begin{array}{c}-0.0075 \\
(0.0010)^{* * *} \\
\end{array}$ & $\begin{array}{c}-0.0006 \\
(0.0002)^{* *}\end{array}$ \\
\hline PCM & $\begin{array}{c}-0.4721 \\
(0.1197)^{* * *}\end{array}$ & $\begin{array}{c}0.1125 \\
(0.0917)\end{array}$ & $\begin{array}{c}-0.5899 \\
(0.0500)^{* * *}\end{array}$ & $\begin{array}{l}-0.0316 \\
(0.0497)\end{array}$ \\
\hline WAGE & $\begin{array}{c}0.0018 \\
(0.0006)^{* * *}\end{array}$ & $\begin{array}{c}0.0015 \\
(0.0018) \\
\end{array}$ & $\begin{array}{c}0.0012 \\
(0.0001)^{* * *}\end{array}$ & $\begin{array}{l}-0.0015 \\
(0.0013) \\
\end{array}$ \\
\hline \multicolumn{5}{|c|}{ Industry variables } \\
\hline IMP COMP & $\begin{array}{c}-0.1686 \\
(0.0396)^{* * *} \\
\end{array}$ & $\begin{array}{c}-0.18991 \\
(0.0386)^{* * *}\end{array}$ & $\begin{array}{l}-0.1125 \\
(0.0917) \\
\end{array}$ & $\begin{array}{c}-0.3023 \\
(0.0890)^{* * *} \\
\end{array}$ \\
\hline $\mathrm{KL}$ & $\begin{array}{c}-0.0016 \\
(0.0001)^{* * *}\end{array}$ & $\begin{array}{c}-0.0018 \\
(0.0001)^{* * *}\end{array}$ & $\begin{array}{c}-0.001 \\
(0.0001)^{* * *}\end{array}$ & $\begin{array}{c}-0.001 \\
(0.0001)^{* * *}\end{array}$ \\
\hline MES & $\begin{array}{c}0.0010 \\
(0.0004)^{* *}\end{array}$ & $\begin{array}{c}0.0011 \\
(0.0007)\end{array}$ & $\begin{array}{c}0.0004 \\
(0.0001)^{* *}\end{array}$ & $\begin{array}{l}-0.0001 \\
(0.0002)\end{array}$ \\
\hline HERF & $\begin{array}{c}-0.4578 \\
(0 . .7367) \\
\end{array}$ & $\begin{array}{l}-0.1422 \\
(0.7166) \\
\end{array}$ & $\begin{array}{c}0.1654 \\
(0.3480) \\
\end{array}$ & $\begin{array}{c}0.4024 \\
(0.1744)^{* *} \\
\end{array}$ \\
\hline GROWTH & $\begin{array}{c}0.2172 \\
(0.2335)\end{array}$ & $\begin{array}{l}-0.1070 \\
(0.3954)\end{array}$ & $\begin{array}{c}0.4549 \\
(0.1888)\end{array}$ & $\begin{array}{c}-0.2490 \\
(0.1176)^{* *}\end{array}$ \\
\hline FP & $\begin{array}{l}-0.4408 \\
(0.6111)\end{array}$ & $\begin{array}{c}0.3954 \\
(0.4006)\end{array}$ & $\begin{array}{c}-0.9287 \\
(0.2933)^{* * *}\end{array}$ & $\begin{array}{l}-0.3243 \\
(0.2543)\end{array}$ \\
\hline
\end{tabular}


End of Table 6

\begin{tabular}{lcccc}
\hline & 1 & 2 & 3 & 4 \\
\hline $\begin{array}{l}\text { Industry } \\
\text { dummies }\end{array}$ & Yes & Yes & Yes & Yes \\
\hline $\begin{array}{l}\text { Time } \\
\text { dummies }\end{array}$ & Yes & Yes & Yes & Yes \\
\hline No. of obs & 149,1344 & 68,276 & 249,792 & 143,175 \\
\hline $\begin{array}{l}\text { No. of } \\
\text { subjects }\end{array}$ & 59,006 & 26,691 & 105,674 & 62,096 \\
\hline $\begin{array}{l}\text { No. of } \\
\text { failures }\end{array}$ & 6,400 & 2,719 & 12,587 & 7,909 \\
\hline $\begin{array}{l}\text { Wald's test } \\
\left(\chi^{2}\right)\end{array}$ & $261,093^{* * *}$ & $70.165^{* * *}$ & $162.10^{* * *}$ & $198.61 * * *$ \\
\hline
\end{tabular}

Notes: $* * *, * *, *$ indicate statistical significance at the 1,5 and 10 percent levels. Standard errors, adjusted for clustering at the firm level, are in parentheses.

Consistently with what we saw in the previous estimations, the results for domestic multinationals are different. Being a domestic multinational is correlated with having higher survival chances in services. More specifically, this result is observed only in the less-knowledge-intensive services, where the probability of exit for DMNEs is 61 percent lower than for NMNEs. In the knowledge intensive services and in manufacturing there is no different behaviour with regard to domestic non-multinational firms.

Turning to the other firm- and industry-specific characteristics, we observe that the results are generally in accordance with our previous results at a more aggregate level. In particular, bigger and more productive firms are found to have a lower risk of exit than smaller and less productive firms. The degree of a firm's R\&D intensity has a positive effect on firm survival only for firms belonging to high and medium-high technology industries in the manufacturing sector. Both in manufacturing and in the services, higher profit margins and lower average wages appear to reduce the hazard ratio only for firms belonging to low and medium-low technology industries in the manufacturing sector and to less-knowledge-intensive services.

As for the industry-specific covariates, our results show that firms in industries with a higher minimum efficient scale have a higher probability of exit in both manufacturing and services sectors of lower technological intensity, whereas capital intensity positively affects the likelihood of survival regardless of the technological level of the sector. In addition, higher levels of industry concentration correspond to an increased probability of firm exit in the knowledge-intensive services. Thirdly, regardless of the technological level of the sector, belonging to import-competing industries increases the chance of survival but only for firms in the less-knowledge-intensive services, while industry growth reduces the risk of exit only in the knowledge intensive industries. Lastly, we find that the share of MNEs in the sector has a positive effect on firm survival in lessknowledge-intensive services, in which the exit risk decreases by more than 50 percent. These effects may be present because domestic non-multinational firms are more imitative and thus more able to absorb the knowledge spillovers from foreign firms. 


\section{Conclusions}

This paper has empirically examined the effects of the presence of MNEs on Italian firm survival, using firm level data for the period 2004-2008. To this end, we first analysed firm survival by distinguishing between foreign multinationals, domestic multinationals and domestic non-multinational firms. The empirical analysis is based on a Kaplan Meyer survival function, as well as a Cox proportional hazard model that compares survival rates for foreign and Italian-owned firms, controlling for several firm and industry covariates. We also examined the effect of foreign presence on the survival of host country firms.

Our main finding reveals that during the period 2004-2008, while manufacturing and service firms owned by foreign MNEs are more likely to exit the market than purely domestic firms, domestic MNEs located in services have a higher chance of survival. These results are obtained even when other firm- and industry-specific variables are controlled for and support the idea that foreign MNEs are inherently footloose. This finding suggests that it is not multinationals per se, but rather foreign multinationals, that are likely to increase firm mortality in Italy. However, in the service sector we found a positive impact of foreign investments on domestic firms, which suggests the presence of spillover effects.

The paper has also investigated how multinational ownership affects the survival prospects of Italian manufacturing and service firms according to the technological intensity of the sector in which firms operate, and has highlighted some differences between static and dynamic industries. In particular, we find that being a domestic multinational has a positive effect on firm survival only in the less-knowledge-intensive services. Conversely, foreign ownership exerts a negative influence on firm survival both in static and dynamic industries, where the chance of exit compared to domestic firms is higher in the less technology- and knowledge-intensive sectors than in the more technology- and knowledge-intensive ones. In addition, we find that the presence of MNEs has a positive impact on the survival of only those firms which operate in the less-knowledge-intensive service sector. This may be explained by the fact that domestic firms are more imitative in these sectors and therefore more able to absorb the knowledge spillovers from foreign firms.

To sum up, it is clear that although there was no clear, a priori indication of the conditional correlation between multinational ownership and exit patterns, our findings nevertheless allow us to draw some general conclusions. Firstly, it is clear that there is a different degree of persistence between foreign and domestic multinationals. This suggests that domestic multinationals are more firmly rooted in the local economy, while foreign MNEs are more swift to change location. A possible explanation for the more rooted nature of Italian multinationals can be found in the particular characteristics of the types of multinational present in Italy. They generally show a lower capacity for internationalisation, are of a local nature and much smaller in size (pocket multinationals) than their correspondent firms in other developed countries. This peculiarity of the Italian model of internationalisation might also explain why we found different results 
from studies concerning other developed countries (Kimura, Fujii 2003; Bandick 2010; Inui et al. 2009).

Secondly, the much higher hazard ratios for FMNEs in low and medium-low technology intensive manufacturing sectors seem to support the hypothesis that the exit behaviour of foreign firms is indeed related to the role of opportunity costs, which are generally quite relevant in less technology intensive sectors, and to the role of sunk costs when setting up production, which (on average) are higher in less traditional sectors, ceteris paribus.

Thirdly, our estimates offer significant implications in terms of different exit behaviour in services. More particularly, the results seem to suggest that firms in services behave in a peculiar way. Domestic multinationals in less-knowledge-intensive services appear more persistent, but FMNEs in services also exhibit lower exit rates, especially as far as less-knowledge-intensive services are concerned. These results suggest that the particular features of services might play an important role. There is, in fact, a range of less-knowledge-intensive services that are more likely to be non tradable and can therefore be supplied to local markets by foreign and domestic firms only through the location in those markets. It is not therefore surprising that activities in these sectors are less volatile.

Finally, our study enriches our understanding of the determinants of firms' survival in Italy and suggests a number of policy implications. In order to increase firm survival, the indications show the importance of adopting ownership-specific incentive policies. Policies should also be calibrated according to the sector involved, taking into account the very different features of manufacturing and services activities, which need to be further investigated with regard to their differing sensitiveness to variables and policy of firm attraction and internationalisation. In this context, incentives to foreign investors appear to be a more appropriate strategy in the service sector, where there are higher positive spillovers on survival induced by the presence of foreign firms. Furthermore, policies that aim to give incentives to domestic multinationals, if they plan to increase the persistence of firms on the markets, should focus on the service sector in particular. In order to raise the probability of survival, policy makers should also target some firmspecific characteristics that are crucial determinants of performance gaps in survival, primarily size and productivity. Our findings should be taken into account in current policies of FDI attraction and firm internationalisation via FDI.

\section{References}

Amendola, A.M.; Pittiglio, R.; Reganati, F. 2012. Are exporters and multinational firms more resilient over a crisis? First evidence for manufacturing enterprises in Italy, Economics Bulletin 32:1914-1926

Alvarez, R.; Görg, H. 2009. Multinationals and plant exit: evidence from Chile, International Review of Economics and Finance 18: 45-51. http://dx.doi.org/10.1016/j.iref.2008.02.011

Audretsch, D. B.1995. Innovation and industry evolution. Cambridge: MIT Press.

Audretsch, D. B.; Mahmood, T. 1995. New-firm survival: new results using a hazard function, Review of Economics and Statistics 77: 97-103. http://dx.doi.org/10.2307/2109995 
Baden-Fuller, C. 1989. Exit from declining industries and the case of steel castings, The Economic Journal 99: 949-961. http://dx.doi.org/10.2307/2234083

Bandick, R. 2010. Multinationals and plant survival, Review of World Economics 146(4): 609634. http://dx.doi.org/10.1007/s10290-010-0068-4

Bernard, A. B.; Sjöholm, F. 2003. Foreign owners and plant survival, NBER Working Paper 10039.

Bernard, A.; Jensen, B. 2007. Firm structure, multinationals and manufacturing plant deaths, Review of Economics and Statistics 89: 193-204. http://dx.doi.org/10.1162/rest.89.2.193

Blanchard, P.; Dhyne, E.; Fuss, C.; Mathieu, C. 2012. (Not so) easy come, (still) easy go? Footloose multinationals revisited, National Bank of Belgium, Working Paper Research No. 223 http://dx.doi.org/10.2139/ssrn.2028921

Burke, A.; Görg, H.; Hanley, A. 2008. The impact of foreign direct investment on new firm survival in the UK: evidence for static versus dynamic industries, Small Business Economics 31: 395-407. http://dx.doi.org/10.1007/s11187-007-9065-y

Castellani, D.; Zanfei, A. 2007. Multinational companies and productivity spillovers: is there a specification error?, Applied Economics Letters 14: 1047-1051.

http://dx.doi.org/10.1080/13504850600706503

Caves, R. 1998. Industrial organization and new findings on the turnover and mobility of firms, Journal of Economic Literature 36(4): 1947-1982.

Colombo, M. G.; Delmastro, M. 2000. A note on the relation between size, ownership status and plant's closure: sunk costs vs. strategic size liability, Economics Letters 69: 421-427.

http://dx.doi.org/10.1016/S0165-1765(00)00309-8

Criscuolo, C.; Martin, R. 2009. Multinationals and U.S. productivity leadership: evidence from Great Britain, The Review of Economics and Statistics 91: 263-281.

http://dx.doi.org/10.1162/rest.91.2.263

De Backer, K.; Sleuwaegen, L. 2003. Does foreign direct investment crowd out domestic entrepreneurship?, Review of Industrial Organization 22: 67-84.

http://dx.doi.org/10.1023/A:1022180317898

Dixit, A.; Pindyck, R. 1994. Investment under uncertainty. Princeton: Princeton University Press.

Dunne, T.; Roberts, M. J.; Samuelson, L. 1988. Patterns of firm entry and exit in US manufacturing industries, Rand Journal of Economics 19: 495-515. http://dx.doi.org/10.2307/2555454

Esteve Pérez, S.; Mañez Castillejo, J. 2008. The resource-based theory of the firm and firm survival, Small Business Economics 30: 231-249. http://dx.doi.org/10.1007/s11187-006-9011-4

Esteve Pérez, S.; Sanchis Lilopis, A.; Sanchis Lilopis, J. A. 2004. The determinants of survival of Spanish manufacturing firms, Review of Industrial Organization 25: 251-273.

http://dx.doi.org/10.1007/s11151-004-1972-3

Ferragina, A.; Pittiglio R.; Reganati, F. 2010. The impact of FDI on firm survival in Italy, in 6th International Scientific Conference Business and Management 2010: Selected papers, May 13-14, Vilnius, Lithuania, 60-66.

Ferragina, A.; Pittiglio R.; Reganati, F. 2012. Multinational status and firm exit in the Italian manufacturing and service sectors, Structural Change and Economic Dynamics 23(4): 363-372. http://dx.doi.org/10.1016/j.strueco.2011.10.002

Flamm, K. 1984. The volatility of offshore investment, Journal of Development Economics 16: 231-248. http://dx.doi.org/10.1016/0304-3878(84)90076-2

Gibson, J. K; Harris, R. I. D. 1996. Trade liberalisation and plant exit in New Zealand manufacturing, The Review of Economics and Statistics 78: 521-29. MIT Press.

http://dx.doi.org/10.2307/2109799 
Giovannetti, G.; Ricchiuti, G.; Velucchi, M. 2009. Size, innovation and internationalization: a survival analysis of Italian firms, Applied Economics 43: 1511-1520.

Girma, S.; Görg, H. 2004. Blessing or curse? Domestic plants survival and employment prospects after foreign acquisition, Applied Economics Quarterly 50: 89-110.

Godart, O.; Görg, H.; Hanley, A. 2012. Surviving the crisis: foreign multinationals versus domestic firms, The World Economy, 35: 305-1321, http://dx.doi.org/10.1111/j.1467-9701.2012.01485.x

Görg, H.; Strobl, E. 2003. Footloose multinationals?, The Manchester School 71: 1-19.

http://dx.doi.org/10.1111/1467-9957.00331

Görg, H.; Strobl, E. 2005. Foreign direct investment and local economic development: beyond productivity spillovers, in T. H. Moran, E. M. Graham, M. Blomström (Eds.). Does foreign direct investment promote development? Washington D. C.: PIIE, 137-157.

Helpman, E.; Melitz, M. J.; Yeaple, S. R. 2004. Export versus. FDI with heterogeneous firms, American Economic Review 94: 300-316. http://dx.doi.org/10.1257/000282804322970814

Hopenhayn, H. A. 1992. Entry, exit and firm dynamics in long run equilibrium, Econometrica 60: $1127-1150$.

Imbriani, C.; Reganati, F. 2002. Do multinational enterprises affect domestic firms' productivity, Studi Economici 5-18.

Inui, T.; Kneller, R.; Matsuura, T.; McGowan, D. 2009. Globalization, productivity and plant exit - evidence from Japan, Rieti Discussion Paper Series 09-E-048.

Jovanovic, B. 1982. Selection and the evolution of industry, Econometrica 50: 649-70.

http://dx.doi.org/10.2307/1912606

Kimura, F.; Fujii, T. 2003. Globalizing activities and the rate of survival: panel data analysis on Japanese firms, Journal of Japanese International Economies 17: 538-560.

http://dx.doi.org/10.1016/j.jjie.2003.08.003

Kimura, F.; Kiyota, K. 2006. Exports, FDI, and productivity: dynamic evidence from Japanese Firms, Review of World Economics 142: 695-719. http://dx.doi.org/10.1007/s10290-006-0089-1

Mata, J.; Portugal, P. 1994. Life duration of new firms, Journal of Industrial Economics 42: 227-245. http://dx.doi.org/10.2307/2950567

Mata, J.; Portugal, P. 2002. The survival of new domestic and foreign-owned firms, Strategic Management Journal 23: 323-343. http://dx.doi.org/10.1002/smj.217

Ozler, S.; Taymaz, E. 2007. Foreign ownership, competition and survival dynamics, Review of Industrial Organization 31: 23-42. http://dx.doi.org/10.1007/s11151-007-9144-x

Pittiglio, R.; Reganati, F.; Sica, E. 2008. Horizontal and vertical spillovers from FDI in the Italian productive system, Quaderni DSEMS 08-2008. Università di Foggia.

Reganati, F.; Sica, E. 2007. Horizontal and vertical spillovers from FDI: evidence from panel data for the Italian manufacturing sector, Journal of Business Economics and Management 8: 259-266.

Simpson, H. 2008. Investment abroad and adjustment at home: evidence from UK multinational firms. The Centre for Market and Public Organization 08/207, Dept. of Economics, University of Bristol.

Strotmann, H. 2007. Entrepreneurial survival, Small Business Economics 28: 87-104. http://dx.doi.org/10.1007/s11187-005-8859-z

Van Beveren, I. 2007. Footloose multinationals in Belgium?, Review of World Economic 143: 483-507. http://dx.doi.org/10.1007/s10290-007-0118-8 
Anna Maria FERRAGINA is Assistant Professor in Economics at the University of Salerno, research fellow at DISES and CELPE (University of Salerno), member of the Steering Committee of FEMISE. Her interests are trade, regional integration, FDI, firm dynamics.

Rosanna PITTIGLIO is Assistant Professor of Economics at the Second University of Naples. She has a Doctorate in Economics (Salerno, Italy), Master in Economics (Naples). At present she is working on her $\mathrm{PhD}$ in Economics (Dundee, UK), carrying out research on Intra-Industry Trade. Her research interests focus on the economics of multinational firms, Intra-Industry trade, International Fragmentation, Industrial Location.

Filippo REGANATI is Professor of Economics at the Department of Communications and Social Research of the University of Rome "Sapienza". He received his PhD in Economics from Reading University (UK). His research focuses on foreign direct investment and productivity spillovers; international trade in imperfect competitive markets; applied industrial organization. 